13. Assessment and prediction of viability and metabolic activity of TILIA PLATYPHYLLOS in arid steppe climate of Ukraine. Y. Lykholat, A. Alekseeva, N. Khromykh, I. Ivan'ko, M. Kharytonov, I. Kovalenko. Agriculture and Forestry. Volume 62. Issue 3: Podgorica. 2016. P. 65-71.

14. Prisedsky $\boldsymbol{Y}$. Activity and isoenzyme composition of peroxidase in Japanese quince vegetative organs under steppe zone conditions. Y. Prisedsky, A. Kabar, Y. Lykholat, N. Martynova, L. Shupranova. BIOLOGIJA. 2017. Vol. 63. No. 2. P. 185-192.

15. AVSA Handbook for Growers, Exhibitors and Judges [PDF version] / URL: http:// www.avsa.org/2016.pdf.

Поступила в редакичию 21.05.2017 г.

УДК $631.48,631.412$

В. М. Вдовиченко

Дніпровський національний університет імені Олеся Гончара

\title{
АНАЛІЗ ПІРОГЕННИХ ПРОЦЕСІВ У ЛІСАХ ДНІПРОПЕТРОВСЬКОГО ОУЛМГ
}

Наведено результати аналізу пірогенних процесів у лісах Дніпропетровського обласного управління лісового та мисливського господарства та даних державного підприсмства «Новомосковський військовий лісгосп» до присднання. Виявлено найбільш пожежонебезпечні підприсмства та закономірності динаміки цих процесів.

Ключові слова: пірогенні процеси, лісгоспи, кількість та площа пожеж.

\section{В. М. Вдовиченко}

Днепровский национальный университет имени Олеся Гончара

\section{АНАЛИЗ ПИРОГЕННЫХ ПРОЦЕССОВ В ЛЕСАХ ДНЕПРОПЕТРОВСКОГО ОУЛОХ}

Приведены результаты анализа пирогенных процессов в лесах Днепропетровского областного управления лесного и охотничьего хозяйства и данных государственного предприятия «Новомосковский военный лесхоз» до присоединения. Выявлены наиболее пожароопасные предприятия и закономерности динамики этих процессов.

Ключевые слова: пирогенные процессы, лесхозы, количество и площадь пожаров.

\author{
V. M. Vdovichenko \\ Oles Honchar Dnipro National University
}

\section{ANALYSIS OF PYROGENIC PROCESSES IN FORESTRY AND HUNTING DEPARTMENT OF DNIPROPETROVSK REGION (FHDDR) FORESTS}

The aim of the work is to analyze the fire danger of Forestry and Hunting Department of Dnipropetrovsk Region (FHDDR) in terms of enterprises and to identify the consistent patterns between the number of fires and the total fire area, as well as the average area of a single case. The basis for the analysis of pyrogenic processes is the reporting form FF (forest fires)-2 "Report on forest fires and their consequences around FHDDR" from 2002 to 2017. In order to generalize the information around Dnipropetrovsk region, the data, taken from the book of forest fires for the period from 2002 to 2014 concerning the state enterprise "Novomoskovsk Military Forestry" of the Ministry of Defense of Ukraine

(C) В. М. Вдовиченко, 2017 
(MOU) until the change of subordination and its inclusion into the Forestry and Hunting Department of Dnipropetrovsk Region, has been included into the reporting indicators as well.

During the formation of the database, the number and area of fires that occurred on forest lands on the whole were taken into account, both on those, covered with forest vegetation and not.

The result of the work lies in the determination of the consistent pattern, associated by the peculiarities of geographical location of enterprises, the mode of use, the functional distribution of plantations, the level of forestry intensiveness, the production capacity of forest enterprises, natural, economic and social conditions. Also, the percentage of pure coniferous plants relative to the total area of lands, covered with forest vegetation, plays an important role.

Two following enterprises appear to be exceptions:

- SE "Novomoskovsk Military Forestry". Predominant number of forest fires occures due to the specificity of the enterprise performance and limited access to the certain areas of coniferous forest plantations that adjoin the military training ground and act as buffer zones in order to ensure life safety of the inhabitants of the surrounding settlements.

- Dniprovsky-Orilsky Nature Reserve. This is owing to the peculiarities of the enterprise performance, limited number of forestry measures, increased fire situation, caused by the considerable clutter of plantations and the inaccessibility of particular forest areas.

The conducted analysis is of great importance when planning the fire protection of the forests of the area and allows to minimize losses, with the proper planning of fire prevention measures.

Keywords: pyrogenic processes, forestry enterprises, number and area of fires.

Пірогенні процеси в степовій частині України відіграють важливу роль у сукцесії соснових лісів. Переважна кількість лісових пожеж зумовлена дією антропогенного впливу суспільства на лісові біогеоценози, наслідки якого є необоротними [1-6]. За офіційними даними, найбільш пожежонебезпечними є східні та південні області, на які припадає 55 \% випадків та 74 \% площі лісових пожеж [3; 5]. Важливу роль у виникненні пірогенних процесів антропогенного характеру відіграє сучасна ситуація в суспільстві. Високий рівень соціальної напруженості $\epsilon$ однією з передумов збільшення кількості випадків виникнення лісових пожеж та зростання їх масштабів [2].

Метою даної роботи є вивчення динаміки виникнення лісових пожеж у Степовій зоні на прикладі соснових лісів Дніпропетровської області.

Матеріали і методи досліджень. За основу для аналізу пірогенних процесів взято форму звітності ЛП-2 «Звіт про лісові пожежі та їх наслідки по Дніпропетровському ОУЛМГ» з 2002 по 2017 рр. Також з метою узагальнення інформації по Дніпропетровській області в цілому до звітних показників було включено дані, взяті з книги лісових пожеж за період з 2002 по 2014 рік по державному підприємству «Новомосковський військовий лісгосп» Міністерства оборони України (МОУ) до моменту зміни підпорядкування та включення його до складу Дніпропетровського обласного управління лісового та мисливського господарства.

Під час формування бази даних бралися до уваги кількість та площа пожеж, що сталися на лісових землях в цілому: як вкритих лісовою рослинністю, так і не вкритих.

Результати та їх обговорення. Детальний аналіз вихідних даних за період з 2002 по 2017 роки по Дніпропетровському ОУЛМГ та ДП «Новомосковський військовий лісгосп» дав змогу систематизувати та впорядкувати пірогенні явища за видом, площею, кількістю у розрізі лісогосподарських підприємств та узагальнити їх для Дніпропетровської області в цілому. Виходячи зі статистичних даних за аналізований період, по Дніпропетровській області зафіксовано 3839 пожеж загальною площею 6712,74 га, в тому числі пройдено верховою пожежею 1310,01 га. Середня площа однієї пожежі становить 1,75 га. 
В табл. 1 наведено відомості про кількість, площу та вид лісових пожеж, які виникли в Дніпропетровській області за період з 2002 по 2017 pp. у розрізі лісогосподарських підприємств.

Відомості про лісові пожежі, які виникли в Дніпропетровській області

Таблиия 1 3а 2002-2017 pp.

\begin{tabular}{|l|c|c|c|c|}
\hline \multicolumn{1}{|c|}{$\begin{array}{c}\text { Найменування лісогосподарського } \\
\text { підприємства області }\end{array}$} & $\begin{array}{c}\text { Кількість } \\
\text { лісових } \\
\text { пожеж }\end{array}$ & $\begin{array}{c}\text { Загальна } \\
\text { площа, га }\end{array}$ & $\begin{array}{c}\text { у т.ч. пройдено } \\
\text { верховою } \\
\text { пожежею, га }\end{array}$ & $\begin{array}{c}\text { Середня } \\
\text { площа, га }\end{array}$ \\
\hline ДП «Васильківський лісгосп» & 164 & 386,21 & 134 & 2,35 \\
\hline ДП «Верхньодніпровський лісгосп» & 7 & 20,6 & 6,2 & 2,94 \\
\hline $\begin{array}{l}\text { Дніпровсько-Орільський природний } \\
\text { заповідник }\end{array}$ & 21 & 105,09 & 22 & 5,00 \\
\hline ДП «Дніпродзержинський лісгосп» & 1026 & 823,75 & 157,59 & 0,80 \\
\hline ДП «Дніпропетровський лісгосп» & 916 & 163,92 & 1,3 & 0,18 \\
\hline ДП «Криворізький лісгосп» & 53 & 35,4 & 0,2 & 0,67 \\
\hline ДП «Марганецький лісгосп» & 157 & 130,19 & 2,92 & 0,83 \\
\hline ДП «Новомосковський лісгосп» & 181 & 46,08 & & 0,25 \\
\hline ДП «Новомосковський військовий лісгосп» & 553 & 4003,76 & 785,9 & 7,24 \\
\hline ДП «Павлоградський лісгосп» & 761 & 997,74 & 199,9 & 1,31 \\
\hline Разом по Дніпропетровській області & 3839 & 6712,74 & 1310,01 & 1,75 \\
\hline
\end{tabular}

Враховуючи дані з рис. 1, можна сказати, що показники по лісогосподарських підприємствах відрізняються між собою і їх можна об'єднати в окремі групи за кількістю випадків. Перша група - до 100 випадків лісових пожеж, друга група - від 100 до 200 випадків, третя група - більше 200 випадків. До першої групи можна віднести три лісогосподарські підприємства, а саме: Дніпровсько-Орільський природний заповідник, ДП «Верхньодніпровський лісгосп» та ДП «Криворізький лісгосп». Відсоток пожеж по першій групі підприємств від загальної кількості пожеж по Дніпропетровській області становить 2,1%. На вищезазначені підприємства припадає відносно мала частка антропогенного навантаження, так як вони розташовані на досить далекій відстані від великих промислових центрів області. Також важливу роль відіграє малий відсоток штучних хвойних насаджень. До другої групи увійшли такі лісогосподарські підприємства, як ДП «Марганецький лісгосп», ДП «Васильківський лісгосп» та ДП «Новомосковський лісгосп». Відсоток пожеж по другій групі становить 13,1%. В третю групу підприємств увійшли лісгоспи з великою кількістю лісових пожеж, а саме ДП «Новомосковський військовий лісгосп», ДП «Павлоградський лісгосп», ДП «Дніпропетровський лісгосп» та ДП «Дніпродзержинський лісгосп». Відсоток пожеж по третій групі найвищий та становить 84,8 \%. Проаналізувавши економіко-географічні умови розташування лісогосподарських підприємств третьої групи, можна стверджувати, що хвойні насадження, які входять до їх складу, розташовані в безпосередній близькості до великих промислових центрів області, таких як м. Дніпро, м. Кам'янське, м. Павлоград та м. Новомосковськ, що, у свою чергу, зумовило значне антропогенне навантаження.

На рис. 2 наведено графік загальної площі лісових пожеж у розрізі лісогосподарських підприємств. Проаналізувавши ці дані, можна виділити чотири групи лісогосподарських підприємств за загальною площею пожеж. Перша група загальна площа лісових пожеж до 100 гектарів, друга група - від 100 до 200 гектарів, третя група - від 200 до 1000 гектарів, четверта група - більше 1000 гектарів. 


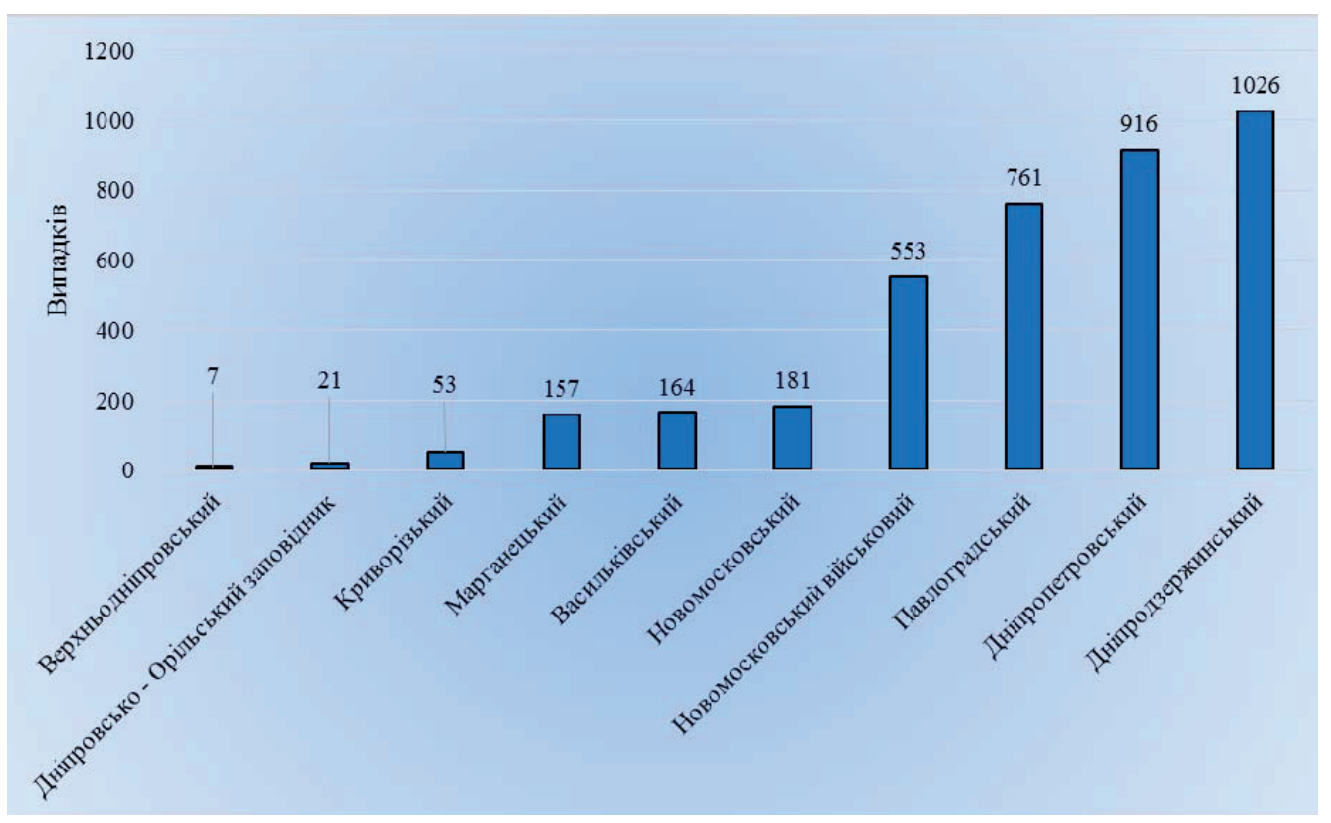

Рис. 1. Кількість випадків виникнення пожеж

До першої групи входять лісгоспи з найменшою площею пожеж, а саме ДП «Верхньодніпровський лісгосп», ДП «Криворізький лісгосп» та ДП «Новомосковський лісгосп». Відсоток площі пожеж по першій групі підприємств від загальної площі пожеж по Дніпропетровській області становить 1,5%. До другої групи входять лісогосподарські підприємства з середньою площею пожеж, а саме Дніпровсько-Орільський природний заповідник, ДП «Дніпропетровський лісгосп», ДП «Марганецький лісгосп». Відсоток площі пожеж по другій групі становить 5,9 \%. До третьої групи входять лісогосподарські підприємства 3 великою

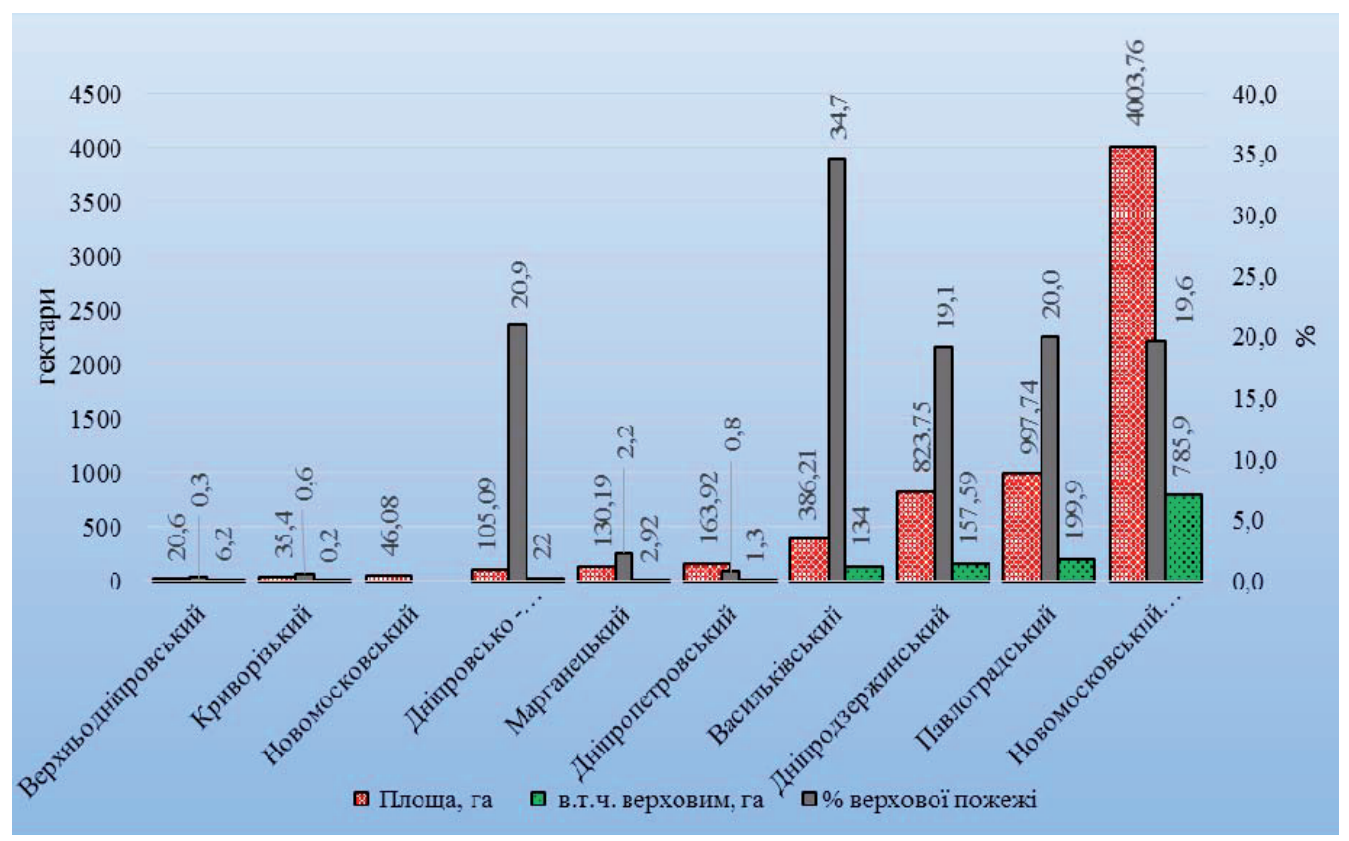

Рис. 2. Загальна площа пожеж, у тому числі верхових 
площею пожеж, а саме ДП «Васильківський лісгосп», ДП «Дніпродзержинський лісгосп», ДП «Павлоградський лісгосп». Відсоток площі пожеж по третій групі становить 32,9 \%. До четвертої групи входить лісогосподарське підприємство 3 дуже великою площею пожеж, а саме ДП «Новомосковський військовий лісгосп». Відсоток площі пожеж по четвертій групі становить 59,6 \%. Слід зазначити, що дане підприємство розташоване в межах діючого загальновійськового полігону на землях запасу МОУ. До 2014 року військовий лісгосп належав до сфери управління МОУ та згідно з розпорядженням Кабінету Міністрів України від 04.09.2013 року № 773-р був переданий цілісним майновим комплексом у підпорядкування Дніпропетровського ОУЛМГ Державного агентства лісових ресурсів України. Лісові насадження, які обслуговує підприємство, в переважній більшості хвойні та виконують роль буферних зон, що, в свою чергу, спричиняє занадто велике пірогенне навантаження.

Також виходячи 3 даних рис. 2, можна співвіднести площі насаджень, пройдених верховими пожежами, до загальної площі лісових пожеж. Середнє співвідношення площ становить $19,5 \%$.

Проаналізувавши середній показник площі (рис. 3 та 4), яка припадає на один випадок виникнення лісової пожежі, можна сказати, що в кожному підприємстві вона різна та коливається в межах від 0,18 га (ДП «Дніпропетровський лісгосп») до 7,24 га (ДП «Новомосковський військовий лісгосп») та в цілому по Дніпропетровській області становить 1,75 га.

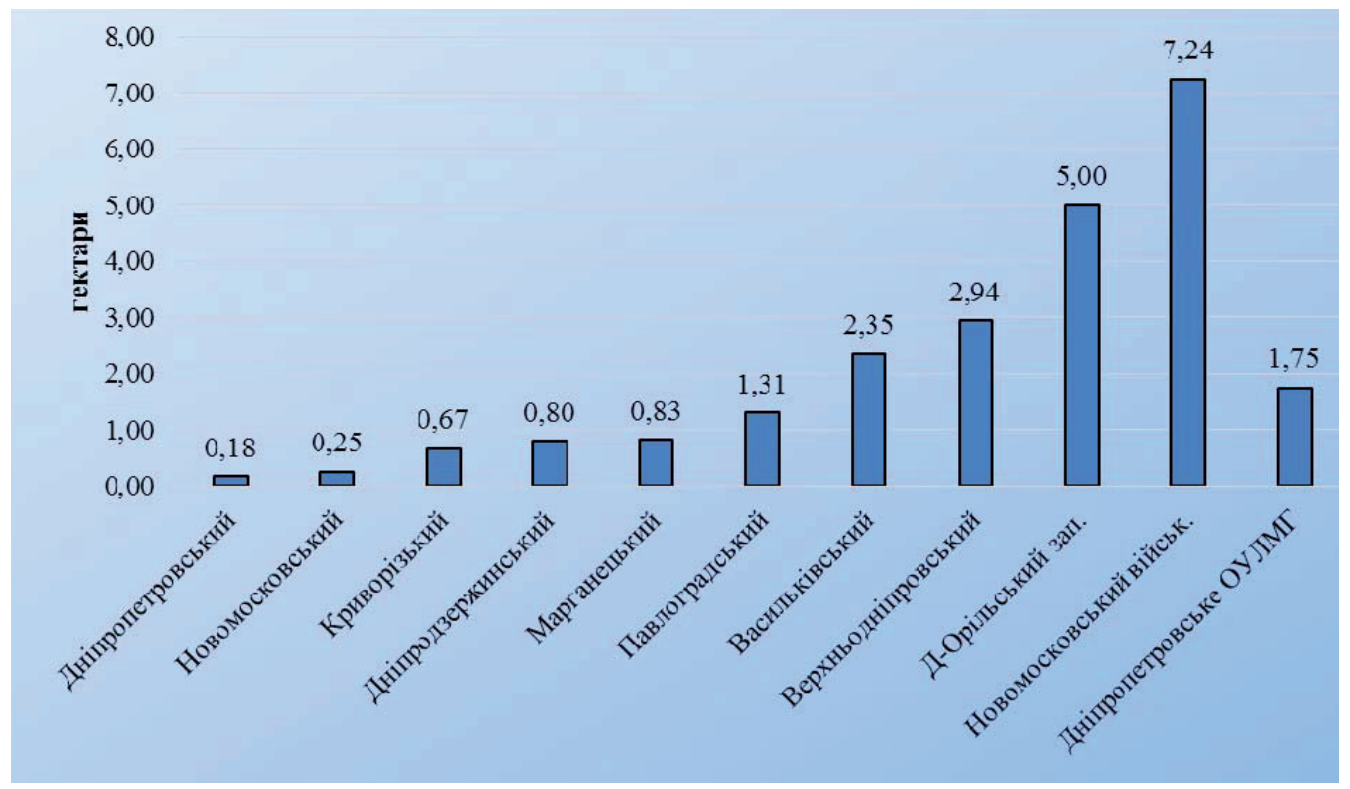

Рис. 3. Середня площа однісї пожежі

Найбільша середня площа лісової пожежі припадає на ДП «Новомосковський військовий лісгосп», це зумовлено особливостями місця розташування підприємства, специфікою роботи та обмеженим режимом доступу до окремих ділянок хвойних насаджень, які примикають до військового полігону та виконують роль буферних зон з метою забезпечення безпеки життя мешканців прилеглих населених пунктів.

Висновки. Таким чином, провівши порівняльний аналіз кількості та площі лісових пожеж, які виникли на території Дніпропетровської області за період 3 2002 по 2017 роки в розрізі лісогосподарських підприємств, встановлено, що в більшості випадків загоряння спричинені антропогенним впливом. Це зумовлено 
особливостями географічного розташування підприємств, режимом користування, функціональним розподілом насаджень, рівнем інтенсивності ведення лісового господарства, виробничою потужністю лісогосподарських підприємств, природними, економічними та соціальними умовами. Також значну роль відіграє відсоткове співвідношення чистих хвойних насаджень до загальної площі вкритих лісовою рослинністю земель.

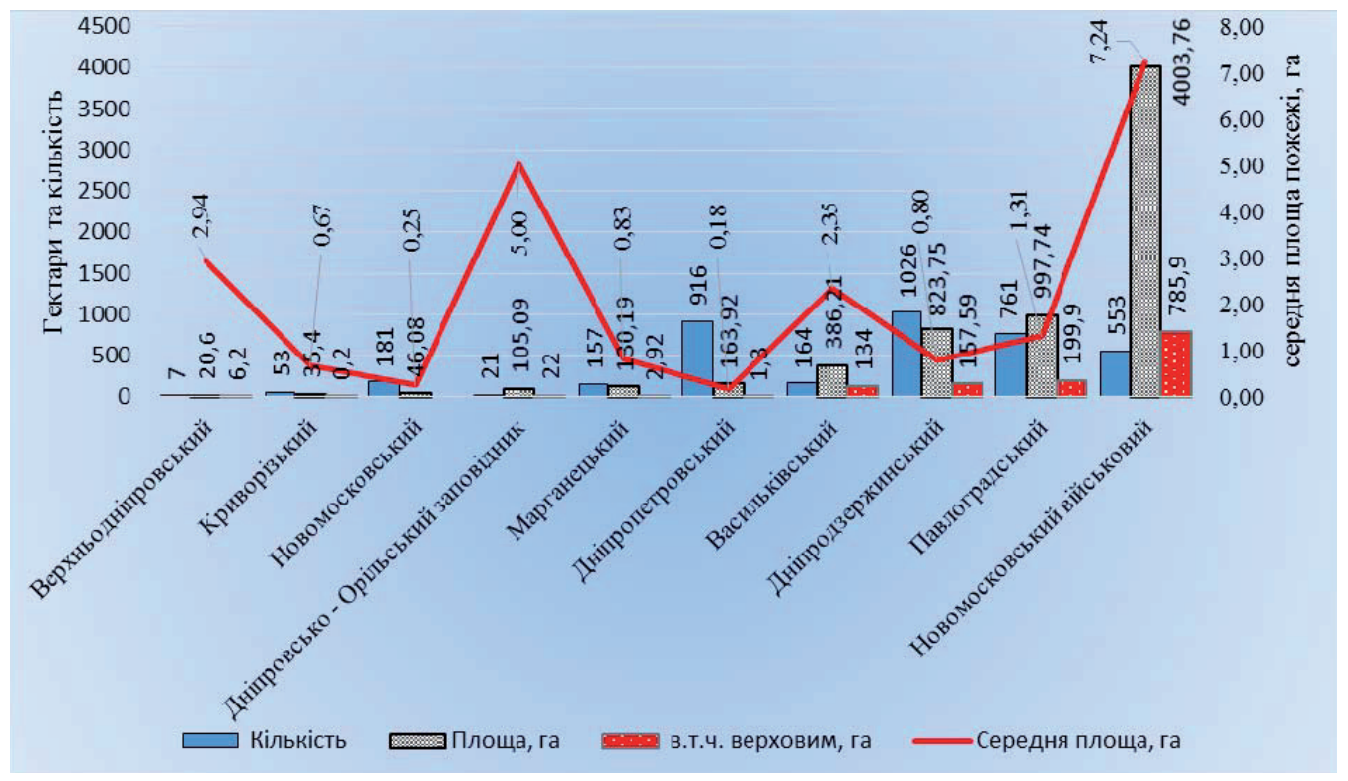

Рис. 4. Кількість, площа (в тому числі верховим) та середня площа пожеж

Винятком є два підприємства:

- ДП «Новомосковський військовий лісгосп». Переважна кількість лісових пожеж зумовлена специфікою роботи підприємства та обмеженим режимом доступу до окремих ділянок хвойних лісових насаджень, які примикають до військового полігону та виконують роль буферних зон з метою забезпечення безпеки життя мешканців прилеглих населених пунктів;

- Дніпровсько-Орільський природний заповідник. Це зумовлено особливостями діяльності підприємства. Обмеженою кількістю лісогосподарських заходів, підвищеною пожежною ситуацією, зумовленою значною захаращеністю насаджень. Важкодоступністю окремих лісових ділянок.

\section{Бібліографічні посилання}

1. Проект організації і розвитку лісового господарства держсавного підприємства «Новомосковський військовий лісгосп" Дніпропетровської і Харківської областей Міністерства оборони Украӥни. Ірпінь. 2011. С. 210.

2. Новіков $\boldsymbol{P}$. Гаряча тема Природа та суспільство. ТОВ «Видавничий дім «ЕКОінформ. 2017. № 21 (177). C. 3.

3. URL:http://dklg.kmu.gov.ua/forest/control/uk/publish/article?art id=118927\&cat $\mathrm{id}=118926$

4. Телицин Г. П., Острошенко В. В. До оцінки екологічної небезпеки лісових пожеж Лісове господарство. 2008. №. 6. С. 44-46.

5. Травлєєв А. П. Моніторингові дослідження лісових екосистем степової зони, їх охорона і раціональне використання. Дніпропетровськ: ДДУ. 1988. 168 с.

6. Юрченко В. В., Манаснков $\boldsymbol{A}$. С. Диференційована оцінка рівня пожежної небезпеки в сосняках посушливої зони. Лісове хазяйство. 2009. № 3. С. 35-37.

Надійшла до редколегії 04.05.2017 p. 